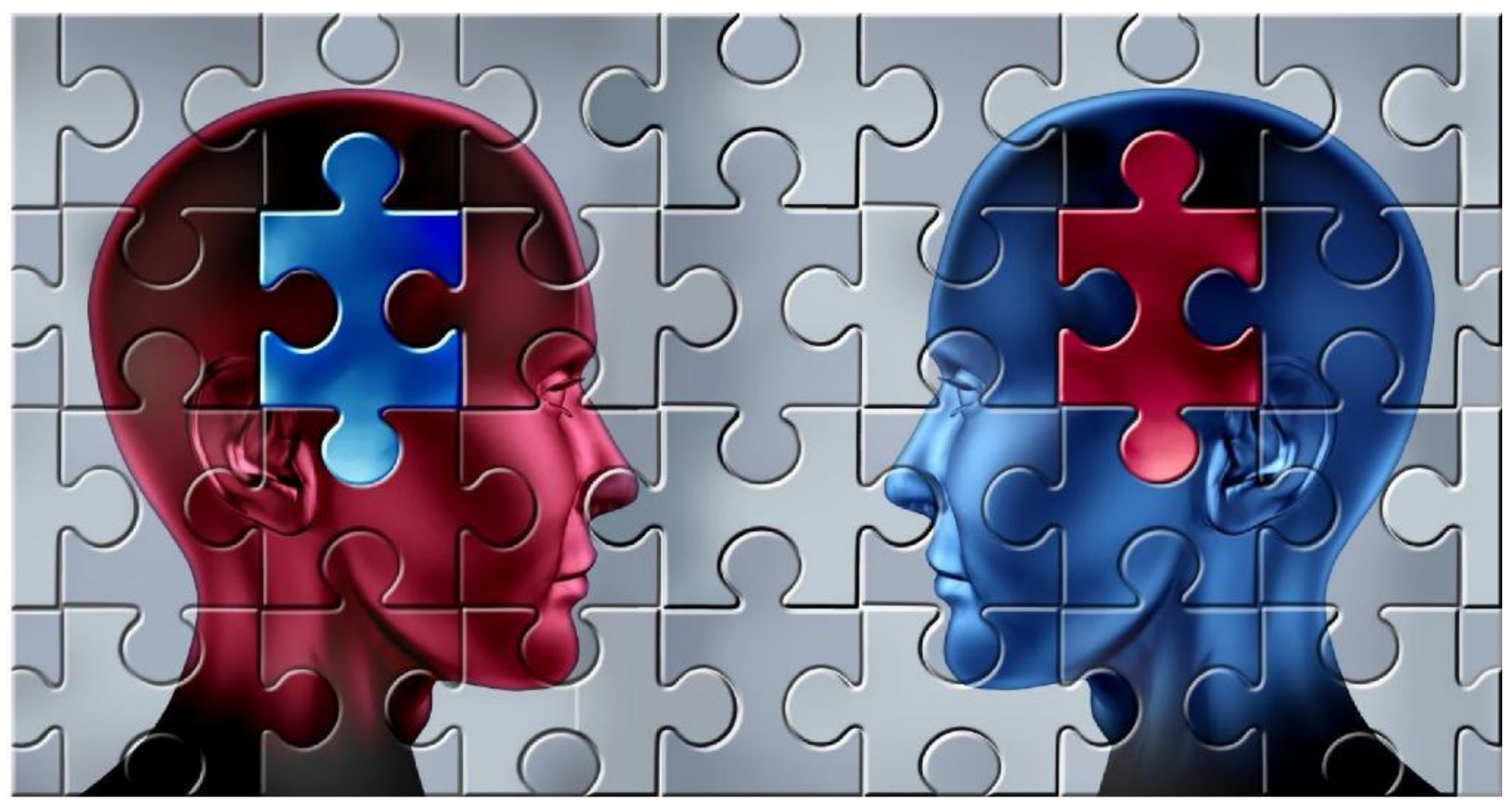

Exchanges: the Warwick Research Journal

Volume 1, Issue 2, April 2014

http://exchanges.warwick.ac.uk

Global Environmental Liability:

Multinational Corporations under Scrutiny

Vidyaranya Chakravarthy Namballa 


\title{
Global Environmental Liability: Multinational Corporations under Scrutiny
}

Vidyaranya Chakravarthy Namballa (University of Warwick)

\begin{abstract}
The purpose of this article is to analyse the extent of international rules that apply to multinational corporations (MNCs) regarding their environmentally degrading activities and quality control qua environmental impact. The first part of the article describes the ambiguous legal status of MNCs and examines the rules that international instruments and host state agreements impose on the activities of MNCs. The second part focuses on jurisdiction and choice of law issues of cross-border litigation and brings out its major shortcoming. Finally, the conclusion comments on the efficiency of international law in imposing environmental liability on MNCs.
\end{abstract}

\section{Introduction}

In an attempt to cut costs, many multinational corporations (MNCs) export their polluting activities through subsidiaries established in less developed countries. This exporting of pollutants is a crucial environmental issue. ${ }^{i}$ Environmental pollution does not necessarily need to cross a country's borders in the form of a substance, it can also pass the frontier through a decision taken in one state leading to environmental consequences in another (Scovazzi, 1991: 395). To put it differently, environmental degradation resulting from the subsidiary's activities can often be traced back to the regulatory orders of the parent company.

Importantly, because MNCs are large contributors to the world's economy (Anderson, 2002: 400), they enjoy a significant political power in the international arena. The paramount position of these corporate giants is not equally balanced against that of the victims when trying to make MNCs liable for environmental damage. More often than not, the cost of production is sought to be curbed by the introduction of environmentally 
unfriendly manufacturing processes and consumables used in production, which slowly but systematically impacts the environment.

Accordingly, the purpose of this article is to analyse the extent of international rules that apply to MNCs regarding their environmentally degrading activities and quality control qua environmental impact. The first part of the article describes the ambiguous legal status of MNCs and examines the rules that international instruments and host state agreements impose on the activities of MNCs. The second part focuses on jurisdiction and choice of law issues of cross-border litigation and brings out its major shortcoming. Finally, the conclusion comments on the efficiency of international law in imposing environmental liability on MNCs.

\section{Regulations of MNCs under International Law}

\section{Controversial Status of MNCs}

By being non-state actors, MNCs are not directly bound by the obligations set down in multilateral environmental agreements (MEAs) between states. Only when governments implement environmental rules on a local level may MNCs come under pressure to enforce them. However, multinational corporations often operate in third world countries, where the environment is not on the agenda of first priorities and judges are resistant in litigating against them. This leads to an alarmingly low quantity and quality of environmental standards that developing countries impose on such corporations.

Shortages in environmental regulation of MNCs are further intensified by the fact that the parent companies of the concerned $\mathrm{MNC}$ and its subsidiaries have separate legal personalities. In addition, the policy-making of the country of origin of the parent company may focus on bulk-production at low costs, as in the case of certain developing countries such as India, China, Bangladesh, Brazil, which eventually compromises the environment in one way or another. Accordingly, neither the 'home' state-where the parent company is established-nor the 'host' country of the subsidiary's location exercise complete control over the functioning of the whole entity of the MNC. As Anderson observes, 'although decision-making within a MNC often occurs within a vertically integrated command structure, that same degree of integration is not available to regulators' (Anderson, 2002: 401). Since multinational corporations conduct their 
business activities simultaneously in many countries, they emphasise their 'ephemeral and shifting legal nature' and avoid governments' scrutiny by 'using their vague national identity to declare themselves free of the law of any country in which they operate' (Macdonald et al, 2000). In other words, MNCs seem to function on the territory of noman's land because the host state cannot reach the regulatory framework of the parent company. For the home state, the subsidiary is located too far from its jurisdictional ambit to cause it to regulate.

Taking into account the ambivalence in the status of multinational corporations, it is generally more beneficial for the victims to sue the parent company for environmental damage than its subsidiary. Among the reasons for such preference are the limited assets of the subsidiary and less favourable local liability law compared to that of the country where the parent company is incorporated (ILA 2004 Report). Still, the legal alternative to establish liability of the parent company is everything but a walk in the park for the victims. Notably, MNCs avoid liability in transboundary environmental litigation by relying on their structural peculiarities and creating a corporate veil between its parent and subsidiary entity. Scovazzi argues that 'although they may be very time-consuming, juridical instruments to pierce the veil and to redress its substantial unfairness are likely to be found in domestic legal systems' (Scovazzi, 1991: 426). Indeed, that might be true, but as the lack of international regulation of MNCs puts the national laws of developing countries under elevated pressure, they might not always live up to their expected efficiency. That apart, it creates an unfair advantage in favour of these corporations when compared to domestic companies doing business in the territory; where the former is free from trappings of elaborate environment protection regulations, the latter finds itself entwined in elaborate regulatory mechanisms, which at times encumber business.

Interestingly, U.S. Chamber of Commerce and some of the country's major polluters have recently argued before the Supreme Court of the USA that the administration had erred in setting up a regulatory framework under the Clean Air Act for stationary sources of carbon dioxide, which regulates emissions from major polluters, like power plants and factories, but not from tens of millions of small operations. They argued that these small operations ought to also be brought within the ambit of the new $\mathrm{CO}^{2}$-pollution rules. From this case, we can see the conflict of interest between the Chamber of Commerce as well as public interest litigation on environment. 


\section{Regulatory Framework of Multinational Corporations (MNCs) MEAs and Soft Law Initiatives}

To start with, MEAs are important in raising environmental standards applicable to MNCs, which are otherwise too dependent on national laws. True, the rules enshrined in MEAs do not bind multinational corporations under international law. However, as the failure to implement required laws on a local level would lead to state liability, governments have a strong stimulus to impose the regulations on polluters. Nevertheless, there seems to be strong resistance by states to establish environmental liability in MEAs. This 'general lack of provision for international environmental liability is reflected in the conspicuous failure to include provisions for such liability in most of the major multilateral environmental agreements between states' (Ong, 2001: 697). Indeed, apart from some sectorial liability instruments and soft law initiatives, international law has remained relatively silent on the crucial issue of corporate environmental responsibility.

The absence of a global environmental liability system is at least partly remedied with the existence of various civil liability regimes. Notably, the international community has paid the most attention to environmental damage resulting from nuclear disasters such as Chernobyl and recently Fukushima (Friedman 2011), and oil slick accidents (Cherry 2011: 56). Taken into consideration the immense risks that such hazardous activities bring along, it is not surprising that states have brought the operators of these particular industries under scrutiny.

Accordingly, international liability framework for marine pollution was agreed upon in two core conventions: the first of which set down the liability for oil pollution (Civil Liabilities Convention, 1970: 45) and the second established a compensation fund (Fund Convention, 1971: 284). ${ }^{\text {ii }}$ The International Convention on Civil Liability for Oil Pollution Damage (Civil Liabilities Convention) imposes strict but limited liability on the ship owner. It also covers damage to the environment _provided compensation for impairment of the environment other than loss of profit from such impairment shall be limited to costs of reasonable measures of reinstatement actually undertaken or to be undertaken' (Civil Liabilities convention, 1970: Article I(6)). Furthermore, nuclear 
activities have been regulated by numerous instruments, ${ }^{\mathrm{iii}}$ which impose absolute limited liability on the operators of nuclear power stations. Similarly to the Civil Liabilities Convention, environmental damage falls within the scope of the Vienna Convention with only 'the costs of measures of reinstatement of impaired environment' being recoverable (Article I (1) $(\mathrm{K}))$.

Where oil tanker and nuclear plant pollution liability schemes have focused only on companies in a limited sector, the regional liability framework of the Council of Europe (Lugano Convention, 1993) and the European Union, with the Environmental Liability Directive (2004/35/EC) impose liability on a wider sector of companies involved in environmentally hazardous activities. For instance, the Lugano Convention foresees strict liability for damage that results from activities harmful to the environment. However, even though the definition of the environment is very broad, the compensation for its impairment is yet again limited 'to the costs of measures of reinstatement actually undertaken or to be undertaken' (Lugano Convention Article 2(7)(C)). Unlike the harmonized civil liability regime of the Lugano Convention, the Environmental Liability Directive excludes traditional civil damage and creates an administrative liability system whereby public authorities must make sure that the polluters remedy damage to the environment. For that purpose, it sets down a two-tier scheme by imposing strict liability for listed hazardous activities and fault-based liability for all other activities causing damage to the EU protected biodiversity.

Certainly, the discussed civil liability regimes are good tools in making the polluter pay as 'externalisation of economic risk is avoided not only on the state level, but ... also on the level of branches and activities creating the risk' (Doeker and Gehring, 1990: 7). Nonetheless, the limited ambit of these schemes stresses their inefficiency in making multinational corporations comply with environmental laws especially because the principle of the - polluter must payl is well recognised under almost all jurisdictions (Ong, 2001: 700). ${ }^{\text {iv }}$ It has also been recognized in all civilized jurisdictions that the polluting unit ought to be shifted out, if not altogether closed (MC Mehta v Union of India and MC Mehta v Kamal Nath \& Ors). Additionally, the principle of strict liability holds that once the activity carried on is considered hazardous or inherently dangerous, the person carrying on such activity is liable to make good the loss caused to any other person by his activity irrespective of the whether he took reasonable care whilst carrying 
on his activity. The rule is premised upon the very nature of the activity undertaken (Indian Council for Enviro- Legal Action v Union of India J.T.). Therefore, in addition to the various liability schemes, there have been a number of soft-law initiatives in order to increase the environmental accountability of these corporations. A relevant example is the United Nations Global Compact, which encourages companies to follow ten general principles in their business activities, including environmental standards (The Ten Principles). ${ }^{\mathrm{v}}$ Another important model is the OECD Guidelines for Multinational Enterprises in which the governments address non-binding recommendations to MNCs (OECD, 2000). These soft-law instruments are definitely a welcome effort in reducing corporate environmental damage but they, nonetheless, lack solid legal force. There is an emerging need to legislate in the said arena for MNCs akin to the introduction of Corporate Social Responsibility (CSR) under Company Law in developing nations.

\section{Transnational Investment Agreements}

The growth of international environmental law as a separate area of public international law began in the 1970s with the Stockholm Conference on the Environment in 1972. Where international treaties, agreements and resolutions created by intergovernmental organisations, as well as national laws and regulations, are being used to protect the environment, the same does not yet completely fulfil the lacuna. Given the limited scope of international liability schemes, it is up to local governments to bridge the gap in MNC regulatory framework. Transnational investment agreements (TIAs) between multinationals and host states, despite being international per se, provide an insight into how efficient the developing countries are in this role (see Ong, 2006).

With the objective to receive profitable investments, third world countries are often willing not to enforce the environmental standards on multinational corporations. Ong remarks that =TIAs are currently designed to operate within an artificially created and maintained legal lacuna, with the only exception being the laws and standards that the MNCs themselves are comfortable with and willing to accept' (Ong, 2006: 205). For instance, the Baku-Tiblisi-Ceyhan (BTC) and Chad-Cameroon pipeline TIA projects emphasise the inadequate environmental responsibility imposed on multinational corporations (Ong, 2006: 189-205). ${ }^{\mathrm{vi}}$ In that event, the environmental issues have been 
far from properly addressed and pollution is usually only recoverable when accompanied by damage to human health or property (Ong, 2006: 208).

The host state's autonomy to regulate foreign investment brings about fear of expropriation. Therefore, the renouncement from possible future legal obligations is a precondition for multinationals to ensure a stable investment environment. However, these investment protection aims have gone too far and '[a] $\mathrm{t}$ least in the environmental field, the — stabilization\| clauses ostensibly introduced to protect foreign investment now actively seek to discourage the implementation of progressively developing international environmental principles within these host states' (Ong, 2006: 206). Still, Verhoosel argues, that these are not the higher standards that multinationals are alarmed about, but rather 'the unexpected change towards a higher standard' and if an investor knows what the future will bring, 'the investment decision can already largely incorporate expected environmental costs' (Verhoosel, 1996: 13-14). In any case, the preventive approach does not find justification exclusively in the oil and nuclear industries but, taking into account the cost of ecological accidents, it is also economically wise elsewhere.

It is important to note, however, that corporate environmental liability is not always a struggle of developing countries against MNCs, but often the two can be found on the same side of the battlefield. As host states can be closely involved in the activities of multinational corporations, they impose liability on these corporations with the same degree of reluctance, as they would accept on themselves. As a result, these multinationals enjoy an outstanding discretion under international law in picking and adopting the pertinent environmental norms. This lack of accountability is further aggravated when considering the difficulties the victims encounter in litigating against multinational corporations.

\section{Transboundary Environmental Litigation Against MNCs}

\section{Jurisdiction}

At the moment, there are no uniform jurisdiction rules for litigating transboundary environmental torts. Thus, some international liability conventions give the plaintiffs a choice of forum, whereas others provide for a single competent court. For example, the Lugano Convention sets down the right to sue 'where damage was suffered; where the 
dangerous activity was conducted; or where the defendant has his habitual residence' (Article 19 (1)). The Vienna Convention, on the other hand, says that the proper forum to hear the case is the court 'within whose territory the nuclear incident occurred' (Article XI (1)). At first sight, it might seem that this leaves the victim a choice but actually the subsequent more specific rules will determine the forum (Bernie and Boyle 2002: 278).

Outside the limited scope of the international conventions discussed in the previous section, the victims are dependent on the rules of private international law in bringing a claim against MNCs. Significantly, there are great differences in the approach of civil and common law countries towards the conflict of laws. In addition, it is the clash between these two systems that convinced the Hague Conference on Private International Law to give up on the idea of drafting a global convention on jurisdiction of transbounday torts (ILA 2004 report: 2.1).

However, in order for a Court to have jurisdiction to entertain a Petition, it must possess jurisdiction both in the domestic sense and under the Rules of Private International Law (Sirdar Gurdyal Singh $v$ The Rajah of Faridkote). Private international law is not law governing relations between independent states but simply a branch of civil law of the state, evolved to do justice between litigating parties in respect of personal statutes involving a foreign element. Thus, the rules of private international law of each state must, by their very nature, differ, but by the comity of nations, certain rules are recognised as common to civilized jurisdiction, which makes it viable whilst choosing the forum to approach for redress.

The EU, chosen here to represent the civil law countries, regulates jurisdiction matters with the 1968 Brussels Convention (Brussels 1 Regulation, 2001). First, the general rule of Article 2 gives jurisdiction to the court of defendant's domicile. Article 5 (3), however, establishes that in matters of tort, the defendant must be sued 'in the courts of the place where the harmful event occurred.' The European Court of Justice has interpreted this to mean that 'the plaintiff has an option to commence proceedings either at the place where damage occurred or the place of the event giving rise to it' (Potassium Mines). This ruling came to be in the light of the interpretation warranted to 
a dispute where the place of the happening of the incident, which may give rise to liability in tort, delict or quasi-delict (Faure 2013), and the place where that incident/ event results in damage are not the same. The expression 'place where the harmful event occurred'-in Article 5 (3) of the Convention of 27 September 1968 on jurisdiction and the enforcement of Judgments in Civil and Commercial Matters-was interpreted as intending to cover both the place where the damage occurred and the place of the event giving rise to it. This resulted in the Plaintiff holding the option to sue in either location. Accordingly, the Dutch plaintiffs in the Potassium Mines case could sue the tortfeasor either in the Netherlands, where the effects of damage were felt, or in France, where the harmful activities of the defendant company were located.

In the majority of the common law systems, the victims can choose a forum but unlike in civil law countries, the courts can resort to the doctrine of forum non-conveniens (Anderson 2002: 412). This concept provides a right to decline jurisdiction if the court finds that there is an alternate better forum to hear the case. For example, the victims of the 1984 Bhopal gas accident attempted to sue the American parent company, which held majority equity shares in the culpable Indian chemical plant (Scovazzi 1991: 403413). India had presented a claim of 'monolithic multinational' and argued that due to the difficulties in finding the answerable entity of the MNC, the victims should have the right to sue in the forum of the location of its central decision-making authority (Scovazzi 1991: 407-408). The court of the United States of America, however, declined jurisdiction and pointed to the Indian court as being a more suitable forum for deciding the case. This proves how difficult it is for the foreign victims to sue the parent company of the country, where the doctrine of forum non-conveniens' can easily be invoked in cases of extraterritorial damage.

In Spilada Maritime Corporation v Cansulex Ltd. it is acknowledged that the factors that the court is entitled to take into account in considering whether one forum is more appropriate are legion. The House of Lords further holds that the authorities do not - and perhaps, cannot-give any clear guidance as to how these factors are to be weighed in any particular case. However, Lord Goff of Chieveley, in his speech in Spilada (supra.), clarifies that the question is not one of convenience, but of the suitability or appropriateness of the relevant jurisdiction, and accordingly, he expresses doubt as to whether the Latin tag forum non-conveniens is apt to describe the principle involved. 
Lord Goff cautions that it is most important not to allow the Latin tag to mislead one into thinking that the question at issue is one of mere practical convenience. Lord Goff cites, with approval, the statement that the object behind the words 'forum nonconveniens' is the forum, which is the more suitable for the ends of justice, and is preferable because pursuit of the litigation in that forum is more likely to secure the ends of justice.

\section{Rationale Behind Choice of Forum as Against Forum Shopping}

As seen in the recent cases and instances, the victims are usually granted a choice of forum in transboundary litigation. Birnie and Boyle, however, are critical about the forum-shopping possibility by saying that a company 'will never be able to predict with certainty where it may be sued or by what laws it will be judged. This is not an approach which benefits access to the environmental justice' (Birnie and Boyle: 279). True, but in transboundary environmental torts it is not always possible to predetermine a single proper forum. The right to choose a forum has, thus, an elevated importance in cases where the defendant is a MNC.

Clearly, it is much easier for the victims to sue in the place where damage was suffered, due to their familiarity with the laws of the country and the smaller costs of litigation. However, with the purpose of getting access to assets and ensuring the enforcement of judgments, the plaintiffs often prefer the courts of the parent company's location. For example, in 1978, the oil tanker Amoco Cadiz sank in the waters of France, bringing about an ecological disaster. All the entities involved in the accident were the subsidiaries of an MNC incorporated in the US (Scovazzi 1991: 413-421). As France was party to the Civil Liabilities Convention channelling liability to the ship owner, the victims could have brought the claim in the French courts. However, they decided to sue the parent company instead, because the US was not party to the Civil Liabilities Convention and had therefore no set the limit on liability (Kiss and Shelton, 2000: 230). Here the victims went forum shopping because they had less favourable conditions in the country where the damage occurred. Therefore, even when there is a possibility to bring a claim in a place where the harm occurred, the victims might still attempt to sue in a more profitable foreign forum. In addition, in this particular case, it was well 
justified because the 'forum non-conveniens' argument was not upheld and the corporate veil of the MNC was successfully broken.

Similarly, it was definitely easier for the Indian court in the Bhopal case to assess damages and gather the multiple claims against the defendant. Still, the forum of the place where the harm was suffered could not serve the best interests of the victims in this case. Not only would the US court have done them more justice regarding the available amount of damages but also the execution of the judgment would have been more likely in the home, rather than the host state of the MNC. Since the parent company hides itself behind the complicated corporate structure, it is often difficult to enforce the judgment against it, which emphasises the importance of the forumshopping opportunity when litigating against MNCs. In the EU, for example, the victims have a double protection in addition to the right to make a complaint in a country where damage was felt, the recognition of the judgments in the host state is also guaranteed (Brussels Convention: Article 31).

Significantly, sometimes the victims do not need to go forum shopping in the first place if the parent company is located in the same country where its subsidiary caused damage. The assets of an MNC and the execution of the judgment would then be within the reach of the victims. For instance, the 1999 Erika oil spill accident off the coast of France lead, inter alia, to a claim against the parent company, who's subsidiary was involved as a charterer in this major ecological catastrophe. The issue of forum shopping did not arise, however, because the parent company, Total SA, was incorporated in the same country, where the victims suffered damage. Similarly to the Amoco Cadiz accident two decades earlier, France was bound by international maritime conventions, which excludes the liability of other tortfeasors apart from the ship owner.

However, in the beginning of 2008 the French Criminal Court gave out a judgment whereby it found the parent company, Total SA, liable for 'causal negligence' in the shipwreck. They jointly sentenced Italian ship-owners and managers, Giuseppe Savarese and Antonio Pollara, the oil group Total SA and the Italian maritime certification company RUNA to pay $€ 192 \mathrm{~m}$ to the plaintiffs who were claiming nearly $€ 1$ bn for damages (Bouniot, 2008). 'For the first time ever in the history of similar cases, the reality of -environmental damage\| was acknowledged' (Bouniot, 2008). This landmark decision called into question long-established precedential procedures and arrangements 
in international maritime law to the benefit of environmentalists, in contrast to the preexisting environment of tolerance to environmental degradation. It was further held, therein, that the judgment debtors were guilty of negligence that had "a causal role" in the catastrophe and "as such brought the disaster about". The magistrates did not pass sentence on the oil company in its quality of charterer for that status would have made it immune to sanctions under international maritime conventions but they circumvented the difficulty by holding it liable for the ship's "vetting" (Bouniot, 2008).

Lastly, the said ruling also upheld the right and locus of the authorities in charge of natural areas and environmental groups to sue for damages, not only for material and moral prejudice, direct or indirect, to collective interests that it is (their) mission to defend, but also for compensation for damage to the environment as cited in supra.

Although the corporate veil was pierced in both the Amoco Cadiz and Erika cases, it is relevant to note that the decision of the US forum was a result of the non-applicability of the Civil Liabilities Convention, whereas the French court used its own creativity and public pressure to find liability of the parent company.

To conclude, forum shopping is certainly necessary in transboundary environmental litigation for it cannot always be predicted whether it is the place where the harm was suffered or the location of dangerous activity that would better serve the interests of the victims. In other words, the suitability of the forum for hearing the case needs to be assessed on a case-by-case basis. For that reason, the approach of providing the victim with a choice of jurisdiction seems to justify itself. As Scovazzi rightly states that _[t] he choice by the victim of the jurisdiction and the law most suitable to deal with its claim for compensation balances the choice by the transnational corporation on the place most suitable to locate its plant and production' (Scovazzi 1991: 427).

\section{Submission to Jurisdiction}

It is further settled by law that a person who voluntarily appears before a foreign Court is bound by the judgment of that Court. However, in British India Steam Navigation Co $\mathrm{v}$ Shammughavilas Cashew Industries \& Ors, paragraph 21 cites, with approval, a passage from Cheshire and North's Private International Law (2008) on submission to jurisdiction, to the effect that a defendant who appears and contests the case on its merits 
will be held to have submitted to the jurisdiction unless the appearance is merely to raise a protest that the court does not have jurisdiction. In this case, the appellant was an English company registered in England carrying on business in England and it did not carry on any business in India. As the carrier under clause 3 of the bill of lading, only the appellant had an option either, to sue or be sued in England or in Cochin - a port of destination - but the shipper had no option to sue at Cochin. In its written statement, it was clearly stated that the appellant had appeared under protest and without prejudice to the contention regarding jurisdiction. It had also pressed this contention at the time of the argument, and, therefore, it could not be said to have submitted to the jurisdiction of Cochin court as it never made any submission or raised any objection as to the fact of short landing.

\section{Contracting on the Choice of Forum}

The jurisdiction of the court may be decided upon by the parties themselves on the basis of various connecting factors. In addition, the parties should be bound by the jurisdiction clause to which they have agreed, unless there are some strong reasons to the contrary.

Any person may contract, either expressly or impliedly, to submit to the jurisdiction of a court to which he would not otherwise be subject. The right of parties to agree to a forum of choice in which to resolve a particular dispute has been recognised (Modi Entertainment Network v W.S.G. Cricket Pte. Ltd). The parties in such circumstances would be bound by the intention and agreement expressed by them in the private inter se contract between them wherein they may either elect a forum of jurisdiction or even confer jurisdiction upon a neutral forum (Cheshire, North \& Fawcett: Private International Law, Oxford University Press 2008).

\section{Judgment in Rem}

A court of a foreign country has jurisdiction to deliver a judgment in rem, which is capable of enforcement or recognition in England or which may be enforced in domestic jurisdiction provided that the subject-matter of the action is property-whether movable or immovable within the foreign country. ${ }^{\text {vii }}$ However, jurisdiction in rem by a court over res, 
i.e. outside the jurisdiction, will not normally be exercised because it will not be recognized by other courts except where the rules of comity permit the same (Rule of 40 of Dicey and Morris).

\section{Applicable Law}

Applicable Law under the settled principles of International Law

There is no global harmonization of choice of law in transboundary environmental disputes but the '[r]ules of private international law normally seek to apply the law of the place where the wrong occurred' (Anderson, 2002: 415). Hence, unlike in forum issues, where at least some general principles apply, the applicable law matters depend completely on national rules (Boyle, 2005: 6). As seen from the Amoco Cadiz case, even when victims have access to justice, it is not guaranteed that the law they wish will be applied. Namely, the court relied on the US law to establish the liability of the MNC but used the less generous French law to decide on the compensation of victims (Scovazzi, 1991: 419). Thus, if the applicable law is not predetermined, one can never really predict the outcome of the case.

Notably, principle 13 of the Rio Declaration invites states to 'develop national law regarding liability and compensation for pollution victims and other the environmental damage ... and to co-operate - in a more expeditious and determined manner\| to develop international law in this respect' (Rio Declaration, 1992). However, until now, the harmonization of national laws in transboundary pollution litigation has been restricted mainly to the areas of oil and nuclear damage. The benefit of those international liability conventions seems to be the fact that they determine the jurisdiction and applicable law issues beforehand. However, if the uniform law provides only for small compensation possibilities, victims are still forced to look for better opportunities elsewhere. Notably, this was also the reason why the French plaintiffs in Amoco Cadiz sued in the US with the hope that American law would be applied.

Harmonization of applicable law has been more ambitious on a European level. The Council of Europe's Lugano Convention is not in force but it is, nevertheless, an important example of an advanced environmental liability regime. As it is based on the 
Brussels Convention, it leaves the victim a choice of jurisdiction but goes a step further and also provides for harmonization of choice of law. Consequently, it specifically determines when strict liability for environmentally dangerous activities arises. If the Lugano Convention would be accepted by a large number of states, it would 'create a common regime of liability for environmental damage regardless of where the action is brought. Thus, considerations of transboundary justice become ultimately inseparable from the substance of the law' (Birnie and Boyle: 279). In other words, there would not be a difference in which European court to bring the case because liability of the operator would be determined according to the same law. Still, it is highly unlikely that such a complex harmonisation convention would be supported on a global level if it has not even succeeded in finding regional support.

It is not surprising that states oppose to extensively prescriptive measures that might interfere with their national civil liability systems. This sensitivity is well reflected in the EU attempt to harmonize rules on environmental liability. These are the same reasons why the Lugano Convention has not been widely ratified, which stands behind the limitations of the Environmental Liability Directive. The Commission had originally proposed to provide strict liability both for traditional and environmental damage (Commission White Paper on Environmental Liability, 2000). However, the Member States rejected, for political reasons, the approximation of national systems on tort law and only administrative liability for environmental damage was agreed upon (Winter et al, 2008: 1-2).

As a result, citizens cannot sue the polluting MNC directly but instead ' $[\mathrm{t}]$ he public authorities act as trustee for ... natural resources and have the authority to file a claim against the operator who caused a significant damage to ... natural resources' (Brans, 2005: 96). Still, it is a comprehensive harmonization of choice of law and has an important impact on transboundary environmental litigation against MNCs. Besides, Article 15 (3) of the Environmental Liability Directive makes clear that even when the polluter of another state causes damage, the Member State has the right to recover remedial measures.

Even though there is no harmonized system of acts of public authorities of other countries, 'it would seem to follow that such claims will have to be brought under a Member State's private law regime, and, if they also constitute a civil and commercial 
matter, will then benefit from the regime of the Brussels I Regulation to obtain effect throughout the EU' (ILA 2004 Report: 2.2). In any event, it is certainly much more difficult for MNCs to avoid environmental responsibility in EU countries because the uniform application of the Environmental Liability Directive puts them under scrutiny by the member states where they operate.

Nevertheless, if the regulation of the activities of MNCs in all countries were harmonized, then it 'would be accused of hindering investment and infringing the sovereignty of host states' (Anderson, 2002: 415). This is why, apart from a small number of transboundary disputes, the choice of law issues in cross-border environmental litigation have been left to be decided by national laws on a case-by-case basis.

\section{Applicable Law under contractual obligations}

Where the law chosen by two or more contracting parties, such as where the law applicable between them is English Law, the law having been chosen, the proper law will be the domestic law of England and the -Proper Law must be the law at the time when the contract is made, throughout the life of the contract, and there cannot be a "floating" proper law.

\section{Liability for Damage to the Environment}

To begin with, civil liability is certainly an important tool for providing compensation for environmental damage. The most significant advantage of civil liability is the reliance on people's initiative in suing MNCs. This is especially crucial in the developing countries, where the governments often do not want to regulate the activities of MNCs and, even less, to bring them to court.

A delicate balance is to be achieved between international obligations and domestic enforcement thereof and while there may be multifarious legal techniques that might address these issues, government policy may place pressure on multinational corporations to comply with these accepted norms. Furthermore, it may also be worthwhile to persuade consumers to only source environmentally sustainable options and specifically 
reject all that is environmentally unviable and erosive, as was done by consistent and committed campaigning by PETA against goods, which were tested upon animals. Another avenue may be for Courts of Law to prioritize and make time-bound suits initiated for common cause by community groups or Non-Governmental Organizations to address the dangers to the environment.

However, harm to property or human health is usually a precondition for addressing environmental concerns under tort system. Hence, even though many international civil liability conventions have acknowledged damage to the environment, they 'generally limit recovery to the costs of reasonable measures of reinstatement and the costs of preventive measures' (Kiss and Shelton, 2000: 229). The difficulty lies, then, in who can claim damages for environmental degradation on unowned territory, such as the global commons. For example, in Amoco Cadiz, the court found it unnecessary to reach the issue of ecological harm because the 'damage was to res nullius and no one had standing to claim compensation' (Kiss and Shelton, 2000: 232). The judge was only willing to uphold the environmental claims that had a connection with civil harm.

As a result, civil liability might not necessarily be the best and only solution for dealing with the problem of corporate environmental pollution but instead 'a system that can draw on taxation, regulation, and criminal sanctions, as well as civil liability' is needed (Anderson, 2002: 425). Further, Daniel opines that ' $[\mathrm{t}]$ he failure to enter into force of many liability regimes ... point[s] to the need to be selective in choosing which environmental problems lend themselves best to a civil liability treaty' (Daniel, 2003: 236). Indeed, tort law system on its own is too narrow in its scope to cover the broad range of environmental damage that MNCs can bring about.

Notably, the EU administrative liability scheme focuses particularly on this side of the coin that tort law fails to deal with. Namely, the Environmental Liability Directive does not require property to have an owner in order for the polluter to become obliged to make up for damage to biodiversity. In addition, the measures that authorities can take are not limited to reinstatement. In a similar situation to Amoco Cadiz, the relevant officials would have a standing to bring a claim against the polluter and recover damages to biodiversity as the guardians of these natural resources. The prospect of such an approach is illustrated by local Erika judgment, where the French court recognized the existence of 'ecological prejudice'. This acknowledgment enables the authorities in charge of natural 
areas and environmental groups 'to sue for damages not only for material and moral prejudice, direct or indirect, to collective interests that it is (their) mission to defend but also for compensation for damage to the environment' (Bouniot 2008). Accordingly, not only could Birdlife recover costs for cleaning and caring for the birds but it also received monetary damages for the cost of replacement of each dead bird (Lepage 2012). Thus, the Erika judgment is a good case in point in showing what really constitutes ecological damage, i.e. the infringement of the environment independently of any commercial considerations, which is not necessarily the type of liability that determines whether damage to the environment can be restored, but rather the recognition of the right of some entities to request it. The existence of such prerogative, however, is once again dependent on each specific legal system. The decision of Paris is one in the nature of a Correctional Court and has to recognize this head of damage and demonstrates the important role that the image of each local government plays within its economic, social and humanist ambit.

\section{Conclusions}

Due to the transboundary structure and functioning of multinational corporations, they need to be subjected to higher laws than national norms and a more stringent regulatory mechanism. Currently, international regulation of environmental liability of MNCs does not provide a comprehensive solution for tackling corporate environmental damage and there is ample scope for development in order to make multinationals more responsive to the impact they have in terms of environmental degradation.

First, the activities of MNCs come within the ambit of global instruments only in a few limited sectors such as maritime and nuclear safety. As MEAs and voluntary guidelines lack the direct and far-reaching effect, MNCs are left under the regulatory autonomy of

the states where they operate. Second, jurisdiction and choice of law matters in transboundary environmental litigation are not subject to international minimum standards and leave a vast scope to care for. Thus, the interpretation of forum shopping and applicable law provisions depends on national rules. The sharp differences in legal systems, however, make litigation against MNCs highly unpredictable. Third, the 
international focus on civil liability regimes is insufficient to extend the liability of MNCs to cover ecological damage.

In conclusion, international law clearly does not determine a holistic liability framework for Multinationals and in some areas of trans boundary litigation; the scarcity of rules would not even pose any problems where national laws fill the lacunae. However, the present excessive reliance on national laws is likely to underestimate the gravity of corporate environmental damage and the need of the hour is a rethink in the comprehensive policy-making at least amongst comity nations.

\section{Bibliography}

International Treaties and Documents

1963 Vienna Convention on Civil Liablity for Nuclear Damage, Vienna, 21 May 1963, in force 12 November 1977, 2 International Legal Materials (1963) 727.

Convention of 27 September 1968 on Jurisdiction and the Enforcement of Judgments in Civil and Commercial Matters, OJ 1972 L 299/32.

'Civil Liabilities Convention', International Convention on Civil Liability for Oil Pollution Damage, Brussels, 29 November 1969, in force 19 June 1975, 9 International Legal Materials (1970) 45.

'Fund Convention', International Convention on the Establishment of an International

Fund for Compensation for Oil Pollution Damage, Brussels, 18 December 1971, in force 16 October 1978, 11 International Legal Materials (1971) 284.

'The Ten principles', available at:

http://unglobalcompact.org/AboutTheGC/TheTenPrinciples/index.html, accessed on 7 November 2008.

Report of the United Nations Conference on Environment and Development, UN Doc. A/CONF.151/26 (12 August 1992).

'Lugano Convention', Convention on Civil Liability for Damage Resulting from Activities Dangerous to the Environment, Lugano, 21 June 1993, European Treaty Series 150 , not yet in force. 
Case Law

British India Steam Navigation Co v Shammughavilas Cashew Industries \& Ors [1990] 1 SCR 884

Indian Council for Enviro- Legal Action v Union of India J.T. [1996] (2) 196

MC Mehta v Union of India and MC Mehta v Kamal Nath \& Ors [13.12.96],the

Hon'ble Supreme Court of India

Modi Entertainment Network v W.S.G. Cricket Pte. Ltd (2003) 4 SCC 341

Potassium Mines, Case 21/76, Handelskwekerij G.J. Bier BV v Mines de

Potasse d'Alsace SA [1976] ECR 1735.

Sirdar Gurdyal Singh v The Rajah of Faridkote (1894) XXI Indian Appeals 171;

R. Viswanathan AIR 1963 SC 1: paragraphs 16, 32, 35 and 136).

Spilada Maritime Corporation v Cansulex Ltd. (1987) A.C. 460, House of Lords

Vellore Citizens Welfare Forum v Union of India \& Ors [28.8.96], the Hon'ble

Supreme Court of India.

European Union Documents

Commission White Paper on Environmental Liability, COM (2000) 66 final, 9 February 2000.

Council Regulation 44/2001 of 22 December 2000 on Jurisdiction and the Recognition and Enforcement of Judgments in Civil and Commercial Matters, OJ 2001 L 12/1.

Directive 2004/35/EC of the European Parliament and of the Council of 21 April 2004 on Environmental Liability with regard to the Prevention and Remedying of Environmental Damage, OJ 2004 L143/56.

\section{Books}

Birnie, P. and A. Boyle, (2002), International Law \& the Environment, $2^{\text {nd }}$ edition, Oxford: Oxford University Press. 
Francioni, F. and T. Scovazzi (eds) (1991), International Responsibility for Environmental Harm, London: Graham \& Trotman

Kiss and D. Shelton (2000), International Environmental Law, $2^{\text {nd }}$ edition, The United States: Transnational Publishers.

Cheshire and North (2008), Private International Law, $11^{\text {th }}$ edition, Oxford: Oxford University Press.

\section{Articles}

Anderson, M. (2002), 'Transnational Corporations and Environmental Damage: Is Tort Law the Answer?', Washburn Law Journal, 41.

Boyle, A.E. (2005), 'Globalising Environmental Liability: The Interplay of National and International Law', JENVTLL, 17.

Bouniot, S. (2008), 'Jugement historique pour l'environnement', 17 January 2008, available at: http://www.humanite.fr/2008-01-17 Societe Erika-jugement-historiquepour-1-environnement; English translation by I. Metral, 'Erika Oil Spill Trial: Landmark Ruling for the Environment', 26 January 2008, http://www.humaniteinenglish.com/article810.html, accessed on 7 November 2008.

Brans, E.H.P. (2005), 'Liability for Damage to Public Natural Resources under the 2004 EC Environmental Liability Directive: Standing and Assessment of Damages', Environmental Law Review, 7.

Cherry, M. A. and J.F. Sneirson (2011), 'Beyond Profit: Rethinking Corporate Social Responsibility and Greenwashing After the BP Oil Disaster', Tulane Law Review, 85 (4): 983-1038.

Daniel, A. (2003), 'Civil Liability Regimes as a Complement to Multilateral Environmental Agreements: Sound International Policy or False Comfort?', Review of European Community \& International Environmental Law, 12 (3): 225-241.

Doeker, G. and T. Gehring (1990), 'Private or International Liability for Transnational Environmental Damage - the Precedent of Conventional Liability Regimes', 2 Journal of Environmental Law. 
Faure, M. (2013) 'Transboundary Pollution', Working paper series, Rotterdam Institute of Law and Economics, http://www.esl.eur.nl/fileadmin/ASSETS/frg/arw/RILE/WP MICHAEL.pdf

Friedman, S.M. (2011), 'Three Mile Island, Chernobyl, and Fukushima: An analysis of traditional and new media coverage of nuclear accidents and radiation', Bulletin of the Atomic Sciences 67 (5): 55-65.

Gouritin, A. (2011), 'The International Regime for the Compensation of Oil-pollution Damage: A Good Candidate to Have a Human Rights Law Approach?' Review of European Community \& International Environmental Law, 20 (2): 194-207.

Macdonald A., Molenaar, H. and P. Pennartz (2000), Controlling Corporate Wrongs: The Liability of Multinational Corporations. Legal Possibilities, Initiatives and Strategies for Civil Society, IRENE, (International Restructuring Education Network Europe), http://www2.warwick.ac.uk/fac/soc/law/elj/lgd/2000_1/irene/ Morgera, E. (2006), 'The UN and Corporate Environmental Responsibility: Between International Regulation and Partnerships', Review of European Community \& International Environmental Law, 15.

Ong, D. (2006), 'The Contribution of State-Multinational Corporation - Transnationall Investment Agreements to International Environmental Law', Yearbook of International Environmental Law.

Ong, D.M. (2001), 'The Impact of Environmental Law on Corporate Governance: International and Comparative Perspectives', EJIL, 12.

U.S. Chamber of Commerce (2000), 'U.S. Chamber Argues Landmark Clean Air Case before the Supreme Court', 6 November 2000, https://www.uschamber.com/press$\underline{\text { release/us-chamber-argues-landmark-clean-air-case-supreme-court }}$ Verhoosel, G. (1996), 'Foreign Investment And Environmental Regulatory Change In Developing And Transition Economies: How To Reconcile The Tension For The Benefit of Technology Transfer', CEPMLP 1. 
Winter, G., Jans, J.H., Macrory, R. And L. Krämer. (2008), 'Weighing Up the EC

Environmental Liability Directive', Journal of Environmental Law, 20 (2): 163-191.

\section{Internet Sources}

http://www.actu-environnement.com

http://www.ila-hq.org

http://www.humaniteinenglish.com

http://www.irene-network.nl

http://unglobalcompact.org

http://www.oecd.org

http://www.westlaw.co.uk

http://www.lexis.com

\section{Endnotes}

'The term 'Multinational Corporation' is used in this paper to refer to all international enterprises, regardless their structure, which operates in more than one country at a time.

ii. As the Civil Liabilities Convention and the Fund Convention have been replaced by two Protocols in 1992, this paper refers to the texts of the Conventions as superseded by these amendments.

iii As an elaborate discussion of all nuclear liability conventions of first and second generation is beyond the scope of this article, the further references will only be made to the global 1963 Vienna Convention on Civil Liability for Nuclear Damage ('Vienna Convention'), Vienna, 21 May 1963, in force 12 November 1977, 2 International Legal Materials (1963) 727, as amended with Protocol in 1997. All the comments, nevertheless, equally apply to the regional nuclear liability regime agreed under the auspices of OECD.

iv Also see Vellore Citizens Welfare Forum v Union of India \& Ors.

v Note that Principles 7-9 deal specifically with the environment. For a detailed discussion on the United Nations Global Compact see E. Morgera, 'The UN and 
Corporate Environmental Responsibility: Between International Regulation and Partnerships', 15 RECIEL (2006), 98-101

vi See Ong, 189-205 for a thorough analysis of BTC pipeline and Chad Cameroon TIA pipeline projects.

vii In Re Spiliada Maritime Corporation, 1987 AC 460; Goods of Coode (1867) 16 LT 746; In Re Goods of Hannah Tucker (1864) 3 SW \& Tr 585; and Evans v. Burrell (1859) 4 SW \& $\operatorname{Tr} 185$. 